\title{
The Curriculum Reform Strategy of Building Materials in Higher Vocational Colleges Under the Background of "Three Educations" Reform
}

\author{
Jing Sun* \\ Chongqing Energy College, Chongqing 402260, China \\ *Corresponding author: Jing Sun, 757809546@qq.com
}

Copyright: ( $) 2022$ Author(s). This is an open-access article distributed under the terms of the Creative Commons Attribution License (CC BY 4.0), permitting distribution and reproduction in any medium, provided the original work is cited.

\begin{abstract}
With the deepening of the "three educations" reform, it has been emphasized that higher vocational colleges should strengthen the improvement of talent training strategies, improve the school-running quality, and explore from three aspects (teachers, teaching materials, and teaching methods) to improve the teaching efficiency and quality. Taking the teaching contents of Building Materials in higher vocational colleges as the research idea, this paper analyzes the current situation of the curriculum reform under the background of "three educations" reform and explores the corresponding reform strategies.
\end{abstract}

Keywords: "Three educations" reform; Higher vocational education; Building Materials; Curriculum reform; Reform strategy

Online publication: January 20, 2022

\section{Introduction}

The Implementation Plan of National Vocational Education Reform put forward the reform task of "three educations" in order to improve students' professional quality as well as provide enterprises with highquality and highly-skilled technical talents. Building Materials is a basic course content of civil engineering specialty in higher vocational colleges, which involves the detection of materials and buildings in the field of construction engineering. Under the background of "three educations" reform, it is necessary to strengthen the exploration of teaching reform, improve the teaching quality, promote students' innovation, and enable students to better adapt to the current social competition.

\section{Reform of teachers under the background of "three educations" reform}

Under the background of "three educations" reform, teachers are the main body of knowledge dissemination and the main players in curriculum reform. The ability and knowledge mastery of teachers directly affect their teaching quality. Therefore, in the reform of "three educations," it is necessary to strengthen the construction of teachers, polish the teams of teachers to form high-quality and high-level teams, as well as solve the problems in the teaching content, the lack of experience, and disconnection with practice in current teaching ${ }^{[1]}$. In the training of teachers, different training methods should be adopted, such as the "going out" and "please come in" strategies; in addition, excellent double qualified teachers should be promoted through school-enterprise cooperation. 
In regard to the "going out" strategy, it is mainly to send teachers to learn from enterprises and improve their practical skills. From the recruitment of teachers in recent years, the proportions of postgraduates and doctoral students are relatively high, indicating that colleges and universities tend to look out for excellent talents, but these talents often enter colleges and universities directly after completing their studies, thus lacking practical experience ${ }^{[2]}$. In the construction engineering technology specialty, more emphasis is placed on practical and on-site teaching. For teachers, the most direct way to improve their practical teaching skill is for them to gain on-the-job experiences in construction enterprises through schoolenterprise cooperation as well as master the workflow of each link in construction enterprises, in order to be competent for future practical teaching. At the same time, in the process of practice, teachers also need to obtain the inspection qualification certificate and engineer's certificate. Teachers should take advantage of their holidays to get involved in enterprise rotation, ensure their sensitivity to the development of the construction industry, as well as strengthen the enrichment of their own knowledge system and the expansion of professional knowledge. In addition, double qualified teacher teams should be formed ${ }^{[3]}$.

In regard to the "please come in" strategy, the purpose is to hire enterprise personnel and professional technicians to serve as practical teachers in colleges, so that these professionals can communicate face to face with the students and solve their problems and doubts ${ }^{[4]}$. At the same time, it is necessary to strengthen the improvement of professional teachers' engineering quality and lay the foundation for the construction of double qualified teachers through the guidance of enterprise professionals. There is also a need to communicate with frontline employees to promote the growth of teachers. At the same time, the teaching of part-time employees from frontline enterprises can guarantee the vividness of course teaching and improve students' experience in terms of knowledge and technology.

\section{Reform of teaching methods under the background of "three educations" reform}

Under the background of "three educations" reform, the reform of teaching methods is the core of the teaching reform. The most obvious issues in the teaching methods of Building Materials in higher vocational colleges are as follows: first, there is a serious disconnection between theoretical teaching and practical teaching, in which unified practical practice is often carried out after theoretical teaching; second, training is not closely linked to on-the-job teaching; in addition, the on-the-spot training and testing contents and instruments in the education are inconsistent with the actual project, and they do not meet the post requirements; third, the performance evaluation of students is single, and the proportion of practical evaluation content in students' teaching evaluation is relatively small, which has a poor effect on the improvement of students' practical skills; thus, it is not conducive to the cultivation of students' innovative skills ${ }^{[5]}$. It is necessary to consider these three aspects in the reform of teaching methods. It is possible to strengthen students' learning and expand their scope of knowledge by adopting double mixed methods of theory and practice as well as online and offline teaching. However, in actual teaching, under the influence of teaching conditions and other aspects, practical teaching often focuses on experiments after completing theoretical teaching. The knowledge contents of Building Materials are relatively astringent and boring; hence, it is difficult to help students understand only through explanation. Therefore, the organization and observation of practical activities are required for students to have a deeper understanding of the subject ${ }^{[6]}$. In teaching, the combination of theory and practice can be adopted; projects can be assumed as the guidance, while tasks can be assumed as the drive; an integrated teaching mode of combining theory and practice should be implemented, and practical teaching contents should be transferred from traditional classroom to the laboratory, so that teachers can show the students the materials and explain relevant theories at the same time, stimulate students' interest in learning, as well as deepen students' impression. For example, in explaining steel testing, different types of reinforcement samples can be prepared in advance for students 
to observe. At the same time, teachers can also strengthen students' understanding of steel mechanics through cold bending demonstration and on-site stretching.

With the development of science and technology, the forms of teaching are becoming more abundant. Internet technology and intelligent technology have been integrated into classrooms to promote the development of online teaching and enrich teaching resources. Therefore, in teaching, teachers can use MOOC, cloud-based classroom, and other methods to search for high-quality courses online and guide students to learn from different angles and ways through online teaching means, so as to expand students' knowledge and make up for the lack in offline teaching ${ }^{[7]}$. In the case of Building Materials, the updating speed of its teaching materials is relatively slow, but in practical, its speed of update is quick. If the teaching materials are constantly taken as teaching reference, it will inevitably lead to obsolescence of teaching knowledge. Through the integration of science and technology teaching content, QQ group, and WeChat can be used to offer updated relevant materials to students, so as to help them expand their knowledge about construction materials ${ }^{[8]}$.

\section{Reform of teaching materials under the background of "three educations" reform}

Under the "three educations" reform, teaching materials are the carrier of teaching, which determine what should be taught. They play an important role in students' acquisition of knowledge and skills as well as promote the improvement of teaching ability and literacy. In China, the construction industry develops fast. With the development of real estate industry, the types of building materials and detection methods are constantly being innovated. This requires staffs who are highly skilled in detection ${ }^{[9]}$. However, the update speed of its teaching materials is slow, which does not meet the development requirements of the current construction industry. Therefore, in the reform of teaching materials, it is necessary to break the barriers of disciplines, reasonably compile teaching materials according to the enterprise testing process and requirements, integrate the new processes and policies of construction materials into the teaching materials, and carry out testing and classification of various materials in combination with the materials applied in construction engineering. For each kind of material testing, relevant units should be entrusted to carry out practical research, so as to optimize the arrangement of teaching plans based on the actual production of construction enterprises ${ }^{[10]}$. At the same time, there is a need to constantly update the teaching materials, pay attention to new technologies and new materials in the construction industry, as well as integrate the contents of students in obtaining cost engineers and constructors in the future, so as to provide adequate job preparation.

\section{Conclusion}

In conclusion, Building Materials is a practical teaching content in higher vocational colleges. In the development of teaching activities, it is necessary to strengthen the innovation and reform of the curriculum in line with the background of "three educations" reform, optimize teachers, teaching methods, and teaching materials, as well as improve the teaching effect.

\section{Disclosure statement}

The author declares that there is no conflict of interest.

\section{References}

[1] Liu Q, 2021, Discussion on Curriculum Reform of Building Materials and Detection in Higher Vocational Colleges under the Background of Reform of "Three Educations". Modern Property 
Management, 2021(5): 8 .

[2] Liu M, 2021, Discussion on Curriculum Reform of Building Materials and Detection in Higher Vocational Colleges under the Background of Reform of "Three Educations". Sichuan Building Materials, 47(2): 250-251.

[3] Huang L, Xu S, Shen J, 2021, Teaching Status and Reform of "Building Materials and Testing" Experimental Course in Higher Vocational Colleges. Journal of Hubei Open University, 34(5): 153$155,158$.

[4] Xu Y, Niu J, 2020, Teaching Reform in Higher Vocational Colleges from the Perspective of "Building Materials and Testing" Course. Journal of Huzhou Vocational and Technological College, 18(2): 44$46,51$.

[5] Wen Y, 2019, Discussion on Teaching Reform of Building Materials and Testing Course in Higher Vocational Colleges Based on "Internet +". Vocational and Technical Education, 40(35): 41-43.

[6] Yang B, 2020, Discussion on Current Situation and Reform of Building Material Testing Course in Higher Vocational Colleges. Sichuan Cement, 2020(2): 339.

[7] Li W, 2019, Preliminary Study on the Construction of Building Materials and Testing Curriculum Resource Database in Higher Vocational Colleges. Create Living, 2019(11): 2-3.

[8] Luo D, 2018, Research on Teaching Reform of Building Materials and Testing Course in Higher Vocational Colleges. Sichuan Cement, 2018(10): 326.

[9] Kang E, Jiang Q, Yao X, 2010, Discussion on the Teaching of Building Materials and Testing in Higher Vocational Colleges based on the Perspective of Curriculum Ideology and Politics. Intelligence, 2010(20): 28-30.

[10] Luo J, 2020, Teaching Practice and Exploration of Ideological and Political Teaching of Building Material Testing and Acceptance Course in Higher Vocational Colleges. Education Modernization, 7(87): 112-117. 